\title{
Genetic Variability and Correlation Studies of Grain Yield and Related Agronomic Traits in Maize
}

\author{
F. Nzuve ${ }^{1}$, S. Githiri ${ }^{2}$, D. M. Mukunya ${ }^{1} \&$ J. Gethi ${ }^{3}$ \\ ${ }^{1}$ Department of Plant Science and Crop Protection, University of Nairobi, Nairobi, Kenya \\ ${ }^{2}$ Jomo Kenyatta University of Agriculture and Technology, Nairobi, Kenya \\ ${ }^{3}$ International Maize and Wheat Improvement Center (CIMMYT), Mount Pleasant, Harare, Zimbabwe \\ Correspondence: F. Nzuve, Department of Plant Science and Crop Protection, University of Nairobi, P. O. Box \\ 29053-0625, Nairobi, Kenya. E-mail: felistermusembi@gmail.com
}

Received: May 22, 2014 Accepted: June 20, 2014 Online Published: August 15, 2014

doi:10.5539/jas.v6n9p166 URL: http://dx.doi.org/10.5539/jas.v6n9p166

\begin{abstract}
A total of fourty two maize hybrids produced through a full diallel mating design and seven parental inbred lines were evaluated in three sites located at different agro-ecological zones in Kenya to determine the genetic parameters governing the inheritance of grain yield and related agronomical traits. The genetic parameters studied among the traits included the mean performance, genotypic variances, phenotypic variances, genotype by environment variances, broad sense heritability and phenotypic and genotypic correlation coefficients. Significant differences were recorded for all traits studied thereby revealing the diversity of the maize genotypes. The grain yield and days to maturity which showed high heritability had low genotypic variances suggesting the involvement of non-additive gene action which could be utilized through heterosis breeding. Ear height and plant height showed the highest heritability and high genotypic variances suggesting the preponderance of additive gene action. Grain yield was positively and strongly correlated with ear height and plant height. The tall plants with high ear placement gave better yields and this could be attributed to the high dry matter accumulation function carried out by the high number of leaves possessed. The positive relationships observed in this study imply that the desirable traits in these hybrids could be exploited in further breeding activities for the development of composites and synthetics for the resource constrained maize farmers who cannot access hybrid seeds every year.
\end{abstract}

Keywords: maize, grain yield, yield components, genetic variability

\section{Introduction}

Maize is the third most important food crop of the world, after wheat and rice, providing $15 \%$ of the protein, and $19 \%$ of the calories for the developing countries (Shakoor et al., 2007). The maize yield character is influenced by several genes which also interact with various environmental conditions (Bocanski et al., 2009). Thus, the yield has a multiplicative effect on the end product of many factors otherwise referred to as yield components (Zeeshan et al., 2013). These yield components are simply inherited with minimal environmental deviations, and hence selection based on them is more appropriate as opposed to the yield per se (Nagabhushan et al., 2011). The assessment of performance of parental lines based on the yield components could aid in the selection of superior parents for the production of better yielding hybrids (Bocanski et al., 2009). This can successfully be achieved if the genetic parameters which govern inheritance of important agronomic traits are established (Mahiboobsa et al., 2012). In addition, the proper characterization of the physiological traits and their relationships with maize yield and yield components coupled with utilization of the revealed genetic variability could lead to improvement and broadening of the diversity of the maize gene pool (Alake et al., 2008; Al-Tabbal et al., 2012).

The mean values, genotypic and phenotypic variances, heritability, and the correlation coefficients of agronomic traits are some of the key parameters which determine the efficiency of a breeding program. The phenotypic variance explicates the total variance among phenotypes tested in different environments of interest to the plant breeder while the total genotypic variance explains the portion of phenotypic variance attributable to the failure of homogeneity among genotypes in different environments (Sujiprihati et al., 2003). The heritability measures the value of selection for a particular trait in various types of progenies (Al-Tabbal et al., 2012; Lule et al., 2012). 
It encompasses the phenotypic variance attributable to genetic causes which have a predictive function in plant breeding leading to permanent genetic improvement. This is because a genotype could be selected based on the phenotype given that the environmental effect is separated from the total variability (Bello et al., 2012). The knowledge of heritability establishes appropriate selection methods coupled with the prediction of any gains from selection while also helping to establish the magnitude of the genetic effects. Larger genotypic variance is most preferred given that high heritability values can be obtained with genotypes with either small or large genetic progress. High heritability is associated with additive gene effect whereas low heritability is due to dominance and epistasis. The coefficient of variation shows the extent of variability represented by the different characters but it excludes the heritable portion. Conversely, the coefficient of correlations help to measure the level of relationships between the traits and also establish the level at which these traits are mutually different (Bocanski et al., 2009; Nagabhushan et al., 2011). The correlations also give reliable and useful information on nature, extent and direction of selection (Zeeshan et al., 2013). This study aimed at understanding the genetic parameters which govern the inheritance of maize yield and other agronomic traits.

\section{Materials and Methods}

\subsection{Plant Materials}

Seeds of seven inbred lines CML 204, CML 312, CML 373 and CML 384 from CIMMYT; TZMI 102, TZMI 711 and TZMI 712 from IITA were included in this study. Important characteristics of these genotypes are given in Table 1. These maize genotypes were grown at Kenya Agricultural Research Institute (KARI), Kiboko in season 1. At flowering, the genotypes were cross pollinated following a full diallel mating design to generate 42 single cross hybrids. The fourty two single cross hybrids and their seven parents were evaluated for grain yield performance and other traits at the three sites and the experiments were laid out in a randomized complete block design in two replicates.

\subsection{Experimental Sites}

Three sites located in different agro ecological zones were chosen for this study. They included Kenya Agricultural Research Institute (KARI), Kiboko; KARI, Kakamega and Field station, Kabete and their climatic conditions have been outlined in Table 2 .

Table 1. Parentage, origin, genetic background, heterotic groups and ecological adaptation of the maize inbred lines used in the study

\begin{tabular}{lllll}
\hline Inbred line & Pedigree/Parentage & Origin/Source & Heterotic Group & Genetic background and Ecological adaptation \\
\hline CML 204 & [7794]-SELF-4-1-S9-1-4-7-4-5-BB. & CIMMYT & Group B & $\begin{array}{l}\text { Adapted to mid altitude and semitropical areas } \\
\text { of Africa }\end{array}$ \\
& & & Tall, late maturing \\
White grains and a dent texture.
\end{tabular}




\begin{tabular}{|c|c|c|c|c|}
\hline TZMI 711 & $\begin{array}{l}\text { National-1 variety crossed to an } \\
\text { IITA MSV-resistant population, } \\
\text { TZSR. TZSR was developed } \\
\text { through intercrossing four } \\
\text { populations; TZB, TZPB, POP 21, } \\
\text { and POP 22 }\end{array}$ & IITA & Group B & $\begin{array}{l}\text { Adapted to Tropical mid-altitude } \\
\text { Has combined resistance to gray leaf spot, } \\
\text { maize streak virus, Exserohilum turcicum and } \\
\text { Puccinia sorghi } \\
\text { Has semi-dent grain texture }\end{array}$ \\
\hline TZMI 712 & $\begin{array}{l}\text { Pedigree - Selected from a cross } \\
\text { between a mid-altitude inbred line } \\
\text { (TZMI501) from IITA and an } \\
\text { inbred line from CIMMYT (ZSR } \\
923 \text { Sr bulk). }\end{array}$ & IITA & Group B & $\begin{array}{l}\text { Adapted to tropical mid-altitude } \\
\text { Has combined resistance to gray leaf spot, } \\
\text { maize streak virus, Exserohilum turcicum, and } \\
\text { Puccinia sorghi } \\
\text { Has semi-dent grain }\end{array}$ \\
\hline TZMI 102 & $\begin{array}{l}\text { Pedigree } \\
\text { CamInb.TCSel1-13-1-1-1-B. }\end{array}$ & IITA & Group B & $\begin{array}{l}\text { TZMI } 102 \text { was a parent of the best } \\
\text { single-cross hybrid marketed in Plateau State } \\
\text { of Nigeria as ' } 8535-23 \text { ' }\end{array}$ \\
\hline
\end{tabular}

Source Pswarayi and Vivek, (2004); Menkir and Adepoju, (2005); Plant inventory (2004); Generation Challenge Programme, (2006); CIMMYT is International Maize and Wheat Improvement Center; IITA is The International Institute of Tropical Agriculture.

Table 2. Agro-climatic description of the experimental sites

\begin{tabular}{|c|c|c|c|c|c|c|c|c|}
\hline \multirow[b]{2}{*}{ Site } & \multirow{2}{*}{$\begin{array}{l}\text { Agro-ecological } \\
\text { zone }\end{array}$} & \multicolumn{3}{|c|}{ Geographic position } & \multirow{2}{*}{$\begin{array}{l}\text { Mean } \\
\text { annual } \\
\text { Rainfall } \\
(\mathrm{mm})\end{array}$} & \multicolumn{2}{|c|}{ Temperature $\left(0^{\circ} \mathrm{C}\right)$} & \multirow[b]{2}{*}{ Soil type } \\
\hline & & Longitude & Latitude & $\begin{array}{l}\text { Altitude } \\
\text { (m) }\end{array}$ & & Minimum & Maximum & \\
\hline $\begin{array}{l}\text { KARI, } \\
\text { Kiboko }^{\text {i }}\end{array}$ & 5 & $37^{\circ} 75^{\prime} \mathrm{E}$ & $2^{\circ} 15^{\prime} \mathrm{S}$ & 993 & 548 & 17 & 30.6 & $\begin{array}{l}\text { Ferrasols to ferric } \\
\text { luvisol on the old } \\
\text { peneplain and eutric } \\
\text { fluvisol at the bottom } \\
\text { of the river valley }\end{array}$ \\
\hline $\begin{array}{l}\text { KARI, } \\
\text { Kakamega }^{i}\end{array}$ & 2 & $34^{\circ} 45^{\prime} \mathrm{E}$ & $0^{\circ} 16^{\prime} \mathrm{N}$ & 1585 & 1995 & 13 & 28.6 & $\begin{array}{l}\text { Soils are deep, friable, } \\
\text { Basaltic loam, fertile } \\
\text { and well drained }\end{array}$ \\
\hline $\begin{array}{l}\text { Kabete, Field } \\
\text { station, } \\
\text { University of } \\
\text { Nairobii }^{\text {ii }}\end{array}$ & 3 & $36^{\circ} 44^{\prime} \mathrm{E}$ & $\mathrm{I}^{\circ} 15^{\prime} \mathrm{S}$ & 1820 & 1000 & 16 & 23 & $\begin{array}{l}\text { Soils are well-drained, } \\
\text { very deep, dark reddish } \\
\text { brown, friable clay } \\
\text { with acid humic top } \\
\text { soil }\end{array}$ \\
\hline
\end{tabular}

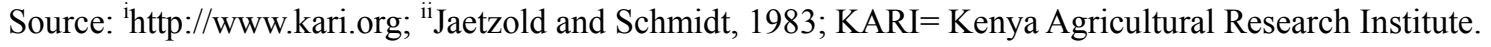

Data were collected during crop growth on days to 50\% female flowering and male flowering (DTFF and DTMF respectively), Stem (SL) and root lodging (RL), plant height, ear height, field weight, moisture content, diseased ears and grain yield. DTFF and DTMF were recorded as the number of days from sowing to when $50 \%$ of the plants have silked and shed pollen respectively. Stem (SL) and root lodging (RL) were recorded as the number of plants lodged at the stem and root respectively and was observed two weeks before harvest. The ear height (EH) was recorded as the height from the ground to the node bearing the uppermost ear while the plant height ( $\mathrm{PH})$ was recorded as the height from the soil level to the node of the flag leaf. Grain yield data was recorded as follows: the ears from each plot were harvested and weighed (field weight); Moisture content was then determined from a seed sample of ten randomly selected cobs. The harvested cobs were then adjusted to $13 \%$ moisture content while assuming an $80 \%$ shelling percentage to calculate the grain yield in tonnes per hectare. 


\subsection{Data Analysis}

\subsubsection{Analysis of Variance}

Analysis of variance (ANOVA) was carried out to establish the level of significance among genotypes using the DIALLEL-SAS program. The mean values were compared using the least significant difference (LSD) procedure.

\subsubsection{The Combining Ability Tests}

This was done based on the Griffing's (1956) method I involving parents, F1's and reciprocals and a standard combining ability model (model 1) using the using DIALLEL-SAS program.

The statistical model was

$$
Y_{i j}=m+g_{i}+g_{j}+s_{i j}+r_{i j}+1 / b c \sum \sum e_{i j k l}
$$

Where

$\mathrm{i}, \mathrm{j}=1,2, \ldots \mathrm{n} ; \mathrm{k}=1,2, \ldots \mathrm{b}$ and $\mathrm{l}=1,2, \ldots \mathrm{c}$;

$\mathrm{Y}_{\mathrm{ij}}=1 / \mathrm{bc} \sum \sum \mathrm{Y}_{\mathrm{ijkl}}=$ mean of ixj ${ }^{\text {th }}$ genotype over $\mathrm{k}$ and $\mathrm{l}$;

$g_{i}=$ GCA effect of $i^{\text {th }}$ parent, $g_{j}=$ GCA effect of $j^{\text {th }}$ parent;

$\mathrm{s}_{\mathrm{ij}}$ is the interaction (SCA effect), $\mathrm{r}_{\mathrm{ij}}$ is the reciprocal effect and $1 / \mathrm{bc} \sum \sum \mathrm{Y}_{\mathrm{ijkl}}$ is mean error effect.

The relative importance of GCA when compared to the SCA was calculated based on the Baker's Ratio (1978).

$$
2 \sigma_{\mathrm{GCA}}^{2} / 2 \sigma_{\mathrm{GCA}}^{2}+\sigma_{\mathrm{GCA}}^{2}
$$

Where

$2 \sigma^{2}{ }_{\mathrm{GCA}}=$ mean square components associated with variance of GCA;

$\sigma^{2}{ }_{\text {SCA }}=$ mean square components associated with variance of SCA.

\subsubsection{Analysis of Phenotypic and Genotypic Variance}

The variability of each quantitative trait was estimated by simple statistical measures including the mean, phenotypic and genotypic variances and coefficient of variation. The phenotypic and genotypic variation and coefficient of variation were calculated following the formulae suggested by Singh and Chaundhary (1979) and Allard (1960). Phenotypic, genotypic and environmental variances were computed from the respective mean squares as indicated below.

i. Genotypic Variance $\left(\delta_{\mathrm{g}}^{2}\right)$ :

Where

$$
\partial_{g}^{2}=\left(M S_{g}-M S_{g l}\right) / r l
$$

$\mathrm{MS}_{\mathrm{g}}=$ mean square of genotype;

$\mathrm{MS}_{\mathrm{gl}}=$ mean square due to genotype by environment interaction;

$1=$ number of locations or environments;

$\mathrm{r}=$ number of replications.

ii. Genotype by environment interaction variance $\left(\delta^{2}{ }_{\mathrm{gl}}\right)$ :

Where

$$
\partial_{g l}^{2}=\left(M S_{g l}-M S_{e}\right) / r
$$

$\mathrm{MS}_{\mathrm{gl}}=$ mean square due to genotype by environment interaction;

$\mathrm{MS}_{\mathrm{e}}=$ error mean square. 
iii. Phenotypic Variance $\left(\delta_{\mathrm{p}}^{2}\right)$ :

Where

$$
\partial^{2}{ }_{p}=\partial^{2}{ }_{g}+\left(\partial 2_{g l} / l\right)+\left(\partial^{2} e / r l\right)
$$

$\delta_{\mathrm{gl}}^{2}=$ mean square due to genotype by environment interaction;

$\delta_{\mathrm{e}}^{2}=$ error mean square.

iv. The genotypic (GCV) and phenotypic (PCV) coefficient of variation were estimated according to the procedure outlined by Johnson et al. (1955) thus:

Where

$$
\begin{gathered}
P C V=\sqrt{\partial^{2}} / X \times 100 \\
G C V=\sqrt{\partial^{2}} / X \times 100
\end{gathered}
$$

$\mathrm{X}=$ population grand mean for the trait considered.

v. Broad-sense heritability $\left(\mathrm{H}^{2}{ }_{\mathrm{BS}}\right)$ was calculated as suggested by Allard (1960) for each character thus:

$$
H_{B S}^{2}=\partial^{2} g / \partial_{p}^{2} \times 100
$$

Where

$\mathrm{H}^{2}{ }_{\mathrm{BS}}=$ heritability in the broad sense.

vi. Phenotypic and genotypic correlations were estimated as suggested by Miller et al., (1958) and Kashiani and Saleh (2010) respectively:

Phenotypic correlation coefficient $\left(\mathrm{rp}_{\mathrm{xy}}\right)$

$$
r p x y=\frac{\partial^{2} p x}{\sqrt{\partial^{2} p x \times 2 p y}}
$$

Genotypic correlation coefficient (rgxy)

$$
r g x y=\frac{\partial g x y}{\sqrt{\partial g x \times 2 g y}}
$$

Where

$r p x y=$ phenotypic correlation coefficient between characters $\mathrm{X}$ and $\mathrm{Y}$ and $r g x y=$ Genotypic correlation coefficients between characters $\mathrm{X}$ and $\mathrm{Y}$.

\section{Results}

The genotype, environment and genotype by environment interaction were significantly different for the traits studied (Table 3). The general and specific combining abilities for all the traits were significantly different. GCA by environment interaction was significantly different for grain yield, maturity, diseased ears and root lodging. The SCA by environment was significantly different for grain yield, plant and ear height, diseased ears and root lodging. The GCA: SCA comparison ranged from 0.3 to 1.7 and the GCA values were also higher than the SCA values for all traits except grain yield and root lodging (Table 3). The coefficient of variation which was used to compare the precision of the experiment with the different means showed that the data was reliable in that the $\% \mathrm{CV}$ for the traits ranged from 0.9 to $18.7 \%$ (Table 3 ). 
Table 3. Values of ' $F$ ' from estimates for grain yield, yield components and other agronomic traits of 7 maize inbred lines and 42 single crosses based evaluated across three environments

\begin{tabular}{|c|c|c|c|c|c|c|c|c|c|}
\hline Traits/Parameters & $\begin{array}{l}\text { Degrees } \\
\text { of } \\
\text { freedom }\end{array}$ & $\begin{array}{l}\text { Grain } \\
\text { Yield } \\
\left(\text { tha }^{-1}\right)\end{array}$ & $\begin{array}{l}\text { DTMF } \\
\text { (days) }\end{array}$ & $\begin{array}{l}\text { DTFF } \\
\text { (days) }\end{array}$ & $\begin{array}{l}\text { Plant } \\
\text { Height } \\
(\mathrm{cm})\end{array}$ & $\begin{array}{l}\text { Ear } \\
\text { Height } \\
(\mathrm{cm})\end{array}$ & $\begin{array}{l}\text { Diseased } \\
\text { ears } \\
\text { (count) }\end{array}$ & $\begin{array}{l}\text { Root } \\
\text { lodging } \\
(\%)\end{array}$ & $\begin{array}{l}\text { Stem } \\
\text { lodging } \\
(\%)\end{array}$ \\
\hline ENV & 2 & $1450.8^{* * *}$ & $891.5^{* * *}$ & $675.5 * * *$ & $262.6^{* * *}$ & $270.7 * * *$ & $163.4 * * *$ & $29 * * *$ & $64.2 * * *$ \\
\hline REP(ENV) & 3 & 17.8 & 4.3 & 3.7 & 3.96 & 4.4 & 1.1 & 1.1 & 0.1 \\
\hline HYBRID & 48 & $19.3^{* * *}$ & $10.3^{* * *}$ & $9.7 * * *$ & $43.2 * * *$ & $34.5^{* * *}$ & $3.1 * * *$ & $16.7 * * *$ & $3.7 * * *$ \\
\hline ENV*HYBRID & 96 & $4.84 * * *$ & $1.7^{* *}$ & $1.4^{*}$ & $2.7 * * *$ & $2.5^{* * *}$ & $2.9 * * *$ & $9.1 * * *$ & $3.6^{* * *}$ \\
\hline GCA & 6 & $15.3^{* * *}$ & $21.3^{* * *}$ & $20.3 * * *$ & $135.9^{* * *}$ & $122.5^{* * *}$ & $8.4 * * *$ & $7.0^{* * *}$ & $15.7 * * *$ \\
\hline SCA & 21 & $39.5^{* * *}$ & $16.1^{* * *}$ & $15.7 * * *$ & $58.5^{* * *}$ & $42.1 * * *$ & $2.8^{* *}$ & $35.3^{* * *}$ & $3.3 * * *$ \\
\hline GCA*Environment & 6 & $7.9 * * *$ & $2.4^{*}$ & $1.9^{* * *}$ & 1.7 & 1.5 & $11.2^{* * *}$ & $13.1 * * *$ & 0.1 \\
\hline $\begin{array}{l}\text { SCA* } \\
\text { Environment }\end{array}$ & 21 & $6.1 * * *$ & 0.6 & 0.5 & $3.0 * * *$ & $3.0 * * *$ & $3.2 * * *$ & $21.5^{* * *}$ & 0.21 \\
\hline GCA:SCA & & 0.6 & 1.1 & 1.1 & 1.4 & 1.5 & 1.5 & 0.3 & 1.7 \\
\hline $\mathrm{CV}(\%)$ & & 18.4 & 3.2 & 3.3 & 5.5 & 7.4 & 3.1 & 0.9 & 1.2 \\
\hline
\end{tabular}

Significance levels $* * *=\mathrm{P}<0.0001, * *=\mathrm{P}<0.001, *=\mathrm{P}<0.05, \mathrm{ENV}=$ Environment, $\mathrm{REP}(\mathrm{ENV})=$ replications, HYBRID = maize hybrids, ENV*HYBRID = environment by hybrid interaction (genotype by environment interaction), $\mathrm{GCA}=$ General combining ability, $\mathrm{SCA}=$ Specific combining ability, GCA*Environment $=$ GCA by environment interaction, $\mathrm{SCA}^{*}$ Environment $=\mathrm{SCA}$ by environment interaction, GCA:SCA $=$ Relative importance of GCA when compared to the SCA based on the Baker's Ratio (1978), CV\% = coefficient of variation; DTMF = days to male flowering, $\mathrm{DTFF}=$ days to female flowering.

The plant height and ear height had the highest genotypic variances, genotype by environment variances, phenotypic variances and heritabilities. The grain yield showed moderate heritability of $74.97 \%$ and low values for genotypic, phenotypic and genotype by environment interaction variances. The stem lodging and diseased ears traits had the least heritability estimates of $7 \%$ and $2 \%$ respectively. They also had the least genotypic variances and phenotypic variances. With regard to the genotypic and phenotypic coefficients of variations, the grain yield had the highest GCV and PCV estimates of $28.6 \%$ and $33.06 \%$ respectively. The plant and ear height had moderate values for GCV and PCV while days to flowering or maturity trait had the least values for GCV and PCV estimates. In this study, the PCV estimates were slightly higher than the GCV estimates (Table 4).

Table 4. Means, estimates of genetic variance, genotype by environment interaction variance, phenotypic variance, broad sense heritability, genotypic coefficient of variation (GCV) and phenotypic coefficient of variation $(\mathrm{PCV})$ for maize grain yield and other agronomic traits in maize

\begin{tabular}{llllllll}
\hline \multirow{2}{*}{ Parameters/Characters } & \multirow{2}{*}{ Mean } & \multicolumn{3}{c}{ Variances } & \multirow{2}{*}{$\mathrm{H}^{2}(\%)$} & \multicolumn{2}{c}{$\mathrm{CV}(\%)$} \\
\cline { 3 - 5 } & & $\sigma_{\mathrm{g}}^{2}$ & $\sigma_{\mathrm{gl}}^{2}$ & $\sigma_{\mathrm{p}}^{2}$ & & $\mathrm{GCV}$ & $\mathrm{PCV}$ \\
\hline Grain yield & 8.16 & 5.46 & 4.04 & 7.28 & 74.97 & 28.62 & 33.06 \\
DTMF & 83.29 & 10.01 & 2.13 & 11.97 & 83.69 & 3.8 & 4.15 \\
DTFF & 85.1 & 11.5 & 1.26 & 13.32 & 86.3 & 3.98 & 4.29 \\
Plant height & 195.57 & 776.32 & 94.79 & 826.99 & 93.87 & 14.25 & 14.7 \\
Ear height & 97.27 & 275.41 & 37.81 & 297.11 & 92.7 & 17.06 & 17.72 \\
Diseased ears & 5 & 0.19 & 28.76 & 2.61 & 7.22 & 8.65 & 32.2 \\
Root lodging & 1.1 & 1.43 & 3.36 & 3.13 & 45.78 & 10.78 & 15.29 \\
Stem lodging & 4.3 & 0.06 & 3.3 & 2.66 & 2.08 & 5.52 & 38.23 \\
Field weight & 4.82 & 11.51 & 1.99 & 0.48 & 68.36 & 11.92 & 14.41 \\
Moisture content & 14.46 & 1.6 & 0.16 & 0.82 & 28.27 & 3.34 & 6.28 \\
\hline
\end{tabular}

$\mathrm{DTMF}=$ days to male flowering, DTFF = days to female flowering; $\sigma_{\mathrm{gl}}^{2}=$ Genotype by environment interaction variance; $\sigma_{\mathrm{g}}^{2}=$ Genotypic Variance; $\sigma_{\mathrm{p}}^{2}=$ Phenotypic Variance; $\mathrm{H}^{2}(\%)=$ Heritability in the broad sense given as a percentage; $\mathrm{GCV}$ genotypic coefficient of variation; $\mathrm{PCV}=$ phenotypic coefficient of variation. 
Grain yield was positively and strongly correlated with ear height, field weight and plant height with high genotypic and phenotypic correlation coefficients (Table 5). Grain yield had a moderate genotypic association with the days to $50 \%$ tasseling and pollen shed. The field weight was positively and strongly correlated with days to maturity, plant and ear height. There was a negative and significantly different correlation between moisture content and ear and plant height, grain yield and field weight. A strong and negative correlation was observed between stem lodging and grain yield.

Table 5. Genotypic $(\mathrm{G})$ and phenotypic $(\mathrm{P})$ correlation coefficients among grain yield and other agronomic traits in maize

\begin{tabular}{|c|c|c|c|c|c|c|c|c|c|c|}
\hline Characters & $\begin{array}{l}\text { Correlation } \\
\text { coefficients }\end{array}$ & DTFF & DTMF & $\begin{array}{c}\text { Ear } \\
\text { Height }\end{array}$ & $\begin{array}{l}\text { Grain } \\
\text { yield }\end{array}$ & $\begin{array}{l}\text { Plant } \\
\text { height }\end{array}$ & $\begin{array}{c}\text { Field } \\
\text { Weight }\end{array}$ & $\begin{array}{c}\text { Moisture } \\
\text { Content }\end{array}$ & $\begin{array}{l}\text { Root } \\
\text { lodging }\end{array}$ & $\begin{array}{l}\text { Stem } \\
\text { lodging }\end{array}$ \\
\hline \multirow{2}{*}{ DTFF } & $\mathrm{G}$ & 1 & $0.98^{*}$ & $0.19 *$ & $0.31 *$ & $0.21 *$ & $0.36^{*}$ & $0.13^{*}$ & 0.07 & -0.05 \\
\hline & $\mathrm{P}$ & 1 & $0.97 *$ & $0.18^{*}$ & $0.47^{*}$ & $0.17^{*}$ & $0.53^{*}$ & 0.1 & 0.07 & -0.04 \\
\hline \multirow{2}{*}{ DTMF } & G & & 1 & $0.20 *$ & $0.29 *$ & $0.24 *$ & $0.36^{*}$ & $0.13^{*}$ & 0.08 & -0.02 \\
\hline & $\mathrm{P}$ & & 1 & $0.18^{*}$ & $0.44 *$ & $0.18^{*}$ & $0.51^{*}$ & 0.11 & 0.06 & -0.03 \\
\hline \multirow{2}{*}{ Ear Height } & G & & & 1 & $0.61 *$ & $0.90^{*}$ & $0.62 *$ & $-0.31 *$ & -0.03 & -0.06 \\
\hline & $\mathrm{P}$ & & & 1 & $0.60 *$ & $0.89^{*}$ & $0.61 *$ & $-0.31^{*}$ & 0.03 & -0.01 \\
\hline \multirow{2}{*}{ Grain yield } & G & & & & 1 & $0.63^{*}$ & $0.96^{*}$ & $-0.35^{*}$ & $-0.18^{*}$ & $-0.48^{*}$ \\
\hline & $\mathrm{P}$ & & & & 1 & $0.61^{*}$ & $0.97 *$ & $-0.36^{*}$ & -0.04 & $-0.34^{*}$ \\
\hline \multirow{2}{*}{ Plant height } & G & & & & & 1 & $0.67 *$ & $-0.28 *$ & -0.07 & -0.11 \\
\hline & $\mathrm{P}$ & & & & & 1 & $0.65^{*}$ & $-0.28 *$ & -0.01 & -0.09 \\
\hline \multirow{2}{*}{ Field Weight } & $\mathrm{G}$ & & & & & & 1 & $-0.24 *$ & $-0.16^{*}$ & $-0.39^{*}$ \\
\hline & $\mathrm{P}$ & & & & & & 1 & $-0.26^{*}$ & 0.17 & $0.08^{*}$ \\
\hline \multirow{2}{*}{$\begin{array}{c}\text { Moisture } \\
\text { Content }\end{array}$} & G & & & & & & & 1 & 0.07 & $0.15^{*}$ \\
\hline & $\mathrm{P}$ & & & & & & & 1 & -0.04 & -0.3 \\
\hline \multirow{2}{*}{ Root lodging } & G & & & & & & & & 1 & $0.27^{*}$ \\
\hline & $\mathrm{P}$ & & & & & & & & 1 & 0.08 \\
\hline \multirow{2}{*}{ Stem lodging } & G & & & & & & & & & 1 \\
\hline & $\mathrm{P}$ & & & & & & & & & 1 \\
\hline
\end{tabular}

Significance levels, $*=\mathrm{P}<0.05 ; \mathrm{G}=$ genotypic correlation coefficients; $\mathrm{P}=$ phenotypic correlation coefficients; $\mathrm{DTMF}=$ days to male flowering, DTFF $=$ days to female flowering.

\section{Discussion}

The significant differences recorded for the different traits among the genotypes studied implied that the maize genotypes included in this study had diverse genetic backgrounds (vashistha et al., 2013; Reddy et al., 2012). Thus, the genetic variability recorded in this study could be exploited by plant breeders to develop varieties adapted to the diverse agricultural practices in sub Saharan Africa to improve food security status (Feuillet et al., 2012). The significant genotype by environment interaction showed a wide variability with regard to the tested genotypes and the environments involved in this study (Alake et al., 2008).

The significant GCA indicated the evidence of additive gene action while the significant SCA implies involvement of non additive gene action. Thus, the differences noted among the traits with regard to the genetic parameters were attributed to both the GCA and SCA values. The relative importance of general and specific combining ability on progeny performance was estimated based on the Baker's Ratio (1978) and it showed a preponderance of additive gene effects in the inheritance of all traits except grain yield and root lodging. Thus, the response of hybrids to these agronomic traits could be predicted based on the GCA of the parents (Gavioli et al., 2006). Thus, the additive effects could be exploited in the introgression of the yield related traits leading to enhance gains from selection (Sese et al., 2002). 
The highest heritability estimates, GCA values and variances were recorded for plant height and ear height. The high heritability estimates and variances suggested that these traits were simply inherited. This also implied that the plant and ear height traits could easily be passed from one generation to the next thence enhancing the efficiency of plant breeding programmes (Shukla et al., 2006). Thus, conventional breeding for these two traits could lead to yield improvement (Lule et al., 2012). The high heritability estimates also explained the preponderance of additive gene actions in the expression of plant height and ear height traits. This is corroborated by the high GCA values for both plant ear height traits. It also indicates that these traits are under genetic control and the environmental factors did not greatly affect their phenotypic variation. Thus, there could be a rapid response to selection for these traits (Shakoor et al., 2007; Akinwale et al., 2011). The improvement or selection for these traits at early segregating generation for the fixable additive gene effects could lead to selection of elite genotypes (Manju \& Sreelathakumary, 2002; Bozokalfa et al., 2010).

The grain yield showed moderately high heritability coupled with the highest GCV and PCV estimates and high SCA estimates. However, it showed low genotypic and phenotypic variances. The preponderance of the SCA effects suggested the involvement of non additive gene action in the grain yield expression. A high number of genes could be involved in the control of grain yield trait (Sujiprihati et al., 2003). The grain yield could be improved through heterosis breeding or hybridization and hybrid vigour (Govindaraj et al., 2011; Bello et al., 2012). Similar results have been reported in other studies (Manju \& Sreelathakumary, 2002; Al-Tabbal et al., 2012).

A high range of genotypic, phenotypic and genotypic by environment variances, genotypic (GCV) and phenotypic (PCV) coefficient of variation were noted for plant height and ear height. The maize genotypes had sufficient variability with regard to these two traits thus genetic improvement could be achieved through selection for these traits hence their critical role in predicting the gains from selection (vashistha et al., 2013; Mustafa et al., 2013). Low GCV and PCV values were observed for days to maturity and this could probably be attributed to the phenotypic plasticity for these traits and also the presence of both positive and negative alleles in the maize genotypes leading to low genetic variation (Akinwale et al., 2011). Similar results were reported by Shakoor et al., 2007) and Manju and Sreelathakumary (2002).

The strong correlation between ear height and plant height with grain yield suggested that tall plants with high ear placement gave better yields compared to the shorter plants with lower ear placement. This could be attributed to the high dry matter accumulation function carried out by the high number of leaves possessed in the case of tall plants. It also implied that the tall lines excelled in capacity to support kernel growth through stem reserve mobilization (Sujipriphati et al., 2003; Al-Tabbal et al., 2012). Grain yield had a moderate genotypic association with days to $50 \%$ tasseling and pollen shed and this could be attributed to the differences among the breeding materials and their genetic behavior in the different environments (Shakoor et al., 2007). There was a strong inherent association between the field weight and most of the yield related traits. Selection based on field weight could lead to grain yield improvement. Generally, correlations among traits are attributed to the genetic nature (pleiotropic effects, linked genes) and environmental factors. The phenotypic correlations arise from genetic and environmental factors and can be marked out by measuring the phenotype while the genetic correlations arise from genetic factors because they give us information about level of relationship between two traits which is additive; crucial in ensuring effective selection (Bocanski, et al., 2009). The positive relationships noted among some of these traits indicated that the desirable genes influencing their inheritance in these hybrids could be exploited in further breeding activities for varietal improvement (Sujiprihati et al., 2003). From this study, there were high genotypic correlation coefficients for plant height and ear height than their corresponding phenotypic values implying presence of a strong inherent relationship implying the presence of genetic association (Zeeshan et al., 2013). Thus, an increase in those traits which show positive and significant correlations could lead to enhanced grain yield (Akinwale et al., 2011). Similar relationships have been reported in previous studies (Kabdal et al., 2003; Shakoor et al., 2007). The genotypic relationships among the traits affecting grain yield explains the true association as they exclude the environmental influences. With positive correlations, genes controlling these traits could be linked or positioned closely together on the same chromosome or could be under the control of pleiotropic genes (Bocanski et al., 2009). On the other hand, low phenotypic correlation coefficients could arise due to the modifying effect of environment on the association character at genetic level (Alake et al., 2008). The positive relationships observed in this study also indicate that favourable genes controlling these traits present in the population could be utilized for the improvement of the population sources in maize breeding programs (Sujiprihati et al., 2003). Thus, the information on correlations among traits remains crucial in improving the efficiency of breeding programs by employing the appropriate selection indices in cultivar or varietal improvement. 


\section{Conclusion}

This study has revealed the existence of adequate genetic variability in the material studied. This knowledge could be crucial in enhancing the efficiency of maize breeding programmes in Kenya. This genetic diversity and the strong genetic association between grain yield and the agronomic traits would aid in indirect selection thus helping the breeders in the development of composites and synthetics for the resource constraint farmers with limited access to hybrid seeds. In addition, the correlation of the highly heritable traits with complex ones could help determine whether selection for one trait has any effect on another. Ear height and plant height traits which showed the highest coefficient of genotypic variability, high broad sense heritability estimates, and had strong positive association with grain yield could be used as effective selection indices for grain yield improvement.

\section{Acknowledgements}

The financial support provided by the Generation Challenge is gratefully acknowledged. CIMMYT and IITA are appreciated for providing the seeds.

\section{References}

Akinwale, M. G., Gregorio, G., Nwilene, F., Akinyele, B. O., Ogunbayo, S. A., \& Odiyi, A. C. (2011). Heritability and correlation coefficient analysis for yield and its components in rice (Oryza sativa L.). African Journal of Plant Science, 5(3), 207-212. Retrieved from http://www.academicjournals.org/ajps

Alake, C. O., Ojo, D. K., Oduwaye, O. A., \& Adekoya, M. A. (2008). Genetic variability and correlation studies in yield and yield related characters of tropical maize (Zea mays L.). Asset Series A, 8(1), 14-27.

Allard, R.W. (1960). Principles of Plant Breeding. John Wiley and Sons, Inc., N.Y.

Al-Tabbal, J. A., \& Al-Fraihat, A. H. (2012). Genetic variation, heritability, phenotypic and genotypic correlation studies for yield and yield components in promising barley genotypes. Journal of Agricultural Science, 4(3), 193.

Bello, O. B., Ige, S. A., Azeez, M. A., Afolabi, M. S., Abdulmaliq, S. Y., \& Mahamood, J. (2012). Heritability and Genetic Advance for Grain Yield and its Component Characters in Maize (Zea Mays L.). International Journal of Plant Research, 2(5), 138-145. http://dx.doi.org/10.5923/j.plant.20120205.01

Bocanski, J., Sreckov, Z., \& Nastasic, A. (2009). Genetic and phenotypic relationship between grain yield and components of grain yield of maize (Zea mays L.). Genetika, 4l(2), 145-154. http://dx.doi.org/10.2298/GENSR0902145B

Bozokalfa, M. K., Lbi, E. D., \& Asçiogul, T. K. (2010). Estimates of genetic variability and association studies in quantitative plant traits of Eruca spp. Landraces. Genetika, 42(3), 501-512. http://dx.doi.org/10.2298/GENSR1003501B

Feuillet, C., Stein, N., Rossini, L., Praud, S., Mayer, K., Schulman, A., ... Appels, R. (2012). Integrating cereal genomics to support innovation in the Triticeae. Funct. Integr. Genomics, 12, 573-583. http://dx.doi.org/10.1007/s10142-012-0300-5

Gavioli, E. A., Perecin, D., \& Mauro, A. O. (2006). Analysis of combining ability in soybean cultivars. Crop Breeding and Applied Biotechnology, 6(2), 121-128. http://dx.doi.org/10.12702/1984-7033.v06n02a02

Generation Challenge Programme, (2006). 2006 Generation Challenge Programme Competitive and Commissioned Research Project Mid-Year Reports. Mexico. D.F.: Generation Challenge Programme.

Govindaraj, M., Selvi, B., Rajarathinam, S., \& Sumathi, P. (2011). Genetic Variability and Heritability of Grain Yield Components and Grain Mineral Concentration in India's Pearl Millet (Pennisetum Glaucum (L) R. Br.) Accessions. African Journal of Food, Agriculture, Nutrition and Development, 11(3), 4758-4771.

Griffing, B. (1956). Concept of General and Specific Combining Ability in relation to Diallel Crossing Systems. Australian Journal of Biological Science, 9, 463-493.

Jaetzold, R., \& Schmidt, H. (1983). Farm Management in Kenya, Vol. II C East Kenya. Ministry of Agriculture, Nairobi, Kenya.

Johnson, H. W., Robinson, H. F., \& Comstock, R. E. (1955). Estimation of genetic and environmental variability in soybeans. Agronomy J, 47, 314-318. http://dx.doi.org/10.2134/agronj1955.00021962004700070009x

Kabdal, M. K., Verma, N. A., \& Panwar, U. B. S. (2003). Genetic variability and correlation studies of yield and its attributing characters in maize (Zea mays L.). Agric. Sci. Digest, 23, 137-139. 
Kashiani, P., \& Saleh, G. (2010). Estimation of genetic correlations on sweet corn inbred lines using SAS mixed model. Am. J Agric Biol Sci, 5, 309-314. http://dx.doi.org/10.3844/ajabssp.2010.309.314

Lule, D., Tesfaye, K., Fetene, M., \& De Villiers, S. (2012). Inheritance and Association of Quantitative Traits in Finger Millet (Eleusine coracana Subsp. Coracana) Landraces Collected from Eastern and South Eastern Africa. International Journal of Genetics, 2(2), 12-21. http://dx.doi.org/10.5829/idosi.ijg.2012.2.2.6390

Mahiboobsa, M., Dharmaraj, P. S., Muniswamy, S., Sony, Y. T., Avinalappa, H., Patil, R., \& Bankar, C. (2012). Genetic variability studies on stable male sterile, maintainer and restorer lines of Pigeonpea [Cajanus Cajan (L.) Millsp.]. Karnataka J. Agric. Sci., 25(4), 525-526.

Manju, P. R., \& Sreelathakumary, I. (2002). Genetic variability, heritability and genetic advance in hot chilli (capsicum chinense jacq.). Journal of Tropical Agriculture. 40, 4-6. Retrieved 23 June, 2014, from http://jtropag.in/index.php/ojs/article/viewFile/75/70

Menkir, A., \& Adepoju, M. A. (2005). Registration of 20 Tropical Mid-altitude Maize Line Sources with Resistance to Gray Leaf Spot. Crop Science. 45, 803-804. http://dx.doi.org/10.2135/cropsci2005.0803.

Miller, P. A., Williams, J. C., Robinson, H. F., \& Comstock, R. E. (1958). Estimates of genotypic and environmental variances and covariances in upland cotton and their implications in selection. Agron. J., 50, 126-131. http://dx.doi.org/10.2134/agronj1958.00021962005000030004x

Mustafa, H. S., Ahsan, M., Aslam, M., Ejaz-ul-Hasan, Q. A., Bibi, T., \& Mehmood, T. (2013). Genetic variability and traits association in maize (zea mays 1.) Accessions under drought stress. J. Agric. Res., 51(3), 231-238. Retrieved 23 June, 2014, from http://www.jar.com.pk/upload/1380534686_106_2._4194_ (ALI).pdf

Nagabhushan, N. M., Mallikarjuna, C. H., Shashibhaskar, M. S., \& Prahalada, G. D. (2011). Genetic variability and correlation studies for yield and related characters in single cross hybrids of maize (Zea mays L.). Current Biotica, 5, 157-163.

Plant Inventory. (2004). No. 213. Plant material produced 2004 (Nos. 634361 to 636444). Retrieved from http://www.ars-grin.gov/npgs/pi_books/plant_inv_213_2004.pdf

Pswarayi, A., \& Vivek, B. (2004). Combining ability of CIMMYT's early maturing maize (Zea mays L.) germplasm under stress and non-stress conditions and identification of testers. Proceedings of the 4th International Crop Science Congress Brisbane, Australia, 26 Sep. - 1 Oct. 2004. ISBN 1920842209.

Rafiq, C. M., Rafique, M., Hussain, A., \& Altaf, M. (2010). Studies on heritability, correlation and path analysis in maize (zea mays 1.) Heritability, correlation and path analysis in maize J. Agric. Res., 48(1), 35-38. Retrieved from http://www.jar.com.pk

Reddy, V. R., Jabeen, F., Sudarshan, M. R., \& Rao, A. S. (2012). Studies on genetic variability, heritability, correlation and path analysis in maize (Zea mays L.) Over locations. International Journal of Applied Biology and Pharmaceutical Technology. 4(1), 196-199. Retrieved from http://www.ijabpt.com

Sese-L. A., \& Staub, J. (2002). Combining ability analysis of yield components in cucumber. J. Amer. Soc. Hort., 127(6), 931-937. Retrieved from http://journal.ashspublications.org/content/127/6/931.full.pdf

Shakoor, M. S., Akbar, M., \& Hussain, A. (2007). Correlation and path coefficients studies of some morphophysiological traits in maize double crosses. Pak. J. Agri. Sci., 44(2), 213-216. Retrieved from http://pakjas.com.pk/papers\%5C315.pdf

Shukla, R. S., Alam, M., Khaliq, A., Bahl, J. R., Singh, H. N., \& Khanuja, S. P. S. (2006). Blossom blight, a new disease of Rauvolfia serpentina. J. Mycol. Plant Pathol, 36, 427-430. Retrieved from http://www.ia.ufrrj.br/cpacs/arquivos/teses_dissert/314_(ME-2012)_Fernando_Silva_Coutinho.pdf

Singh, R. K., \& Chaundhary, B. D. (1979). Biometrical methods in quantitative genetic analysis, Kalyani Publ., New Delhi.

Sujiprihati, S., Saleh, G. B., \& Ali, E. S. (2003). Heritability, performance and correlation studies on single cross hybrids of tropical maize. Asian Journal of Plant Science, 2(1), 51-57. http://dx.doi.org/10.3923/ajps.2003.51.57

Vashistha, A., Dixit, N. N., Dipika, Sharma, S. K., \& Marker, S. (2013). Studies on heritability and genetic advance estimates in Maize genotypes. Bioscience Discovery, 4(2), 165-168. Retrieved from http://biosciencediscovery.com 165 ISSN: 2231-024X 
Zeeshan, M., Ahsan, M., Arshad, W., Ali, S., Hussain, M., \& Khan, M. I. (2013). Estimate of correlated responses for some polygenic parameters in yellow maize (Zea mays L.) hybrids. International Journal of Advanced Research, 1(5), 24-29. Retrieved from http://www.journalijar.com

\section{Copyrights}

Copyright for this article is retained by the author(s), with first publication rights granted to the journal.

This is an open-access article distributed under the terms and conditions of the Creative Commons Attribution license (http://creativecommons.org/licenses/by/3.0/). 